\title{
Consumption of the National Basketball Association in Brazil: the motives of distant fans
}

\author{
Yves Miranda $^{1}$ (D), Yuri Ricardo Rodrigues Borba ${ }^{1}$ (D), Marcos Antonio Barros Filho ${ }^{1}$ (D), \\ Victor Henrique Rodrigues Silva ${ }^{1}$ (D), Carlos Augusto Mulatinho de Queiroz Pedroso ${ }^{1}$ \\ ${ }^{1}$ Universidade de Pernambuco, Grupo de Pesquisa em Esporte e Gestão, Recife, PE, Brazil.
}

Associate Editor: Sandro Carnicelli (D), University of the West of Scotland, Scotland, UK. E-mail: Sandro.Carnicelli@uws.ac.uk.

\begin{abstract}
Aim: This study aimed to analyze, through games, the motives for the consumption of the National Basketball Association (NBA) by Brazilian fans and the influence on the consumption intentions of these fans. Methods: The study has a quantitative approach and used an online questionnaire consisting of nine motives for sports consumption and a dimension to analyze behavioral intentions. The sample consisted of 336 individuals over 18 years of age who declared that they support a team in the competition. Data were analyzed using a two-step Structural Equation Modeling in Amos 26.0. Results: The average age of respondents was 24.20 years $( \pm 6.70)$, mostly men $(91.7 \%)$, with complete high school (45.8\%), single (83.6\%), who watch 3 to 5 NBA games per week $(53.6 \%)$, mostly through the internet (56.8\%), and who do not usually buy NBA-licensed products (58.0\%). Analysis of the causal model indicated that both vicarious achievement $(\beta=0.55 ; \mathrm{p}<0.01)$ and social interaction $(\beta=0.28 ; \mathrm{p}<0.01)$ are motives that positively influenced behavioral intentions related to NBA. Conclusion: Motives such as the acquisition of knowledge, drama, interest in basketball, and knowledge of the game are highly valued by Brazilian fans who consume the NBA. In addition, the fans' sense of accomplishment with their team's victory and the social interaction offered by the games, even if distant, are important factors that influence the behavioral intentions of these fans.
\end{abstract}

Keywords: sports marketing, sports management, basketball, international NBA fan, motivation.

\section{Introduction}

The development of sports organizations today means that they are considered much more than local institutions, but real undertakings endowed with a recognizably strong brand $^{1}$. Common examples can be seen in football, where clubs such as Barcelona, Real Madrid, and Manchester United generate combined revenues of over two billion euros $^{2}$. In the case of the National Basketball Association (NBA), one of the top four North American sports leagues, the three most valuable teams in the competition, the New York Knicks, Golden State Warriors, and Los Angeles Lakers, respectively, are worth more than 14 billion dollars ${ }^{3}$. The grandeur of these organizations makes it clear that they must think globally and expand their brands to foreign markets ${ }^{4}$.

The rise of information technologies has provided unprecedented access to content for fans to connect with the sports team they support, regardless of geographic location, which has led these fans to form ever-stronger ties with teams from other countries ${ }^{5}$. For Pu and James ${ }^{6}$, different from local fans, who are geographically close to the team they support, distant fans can be considered individuals who follow a sports team that is far away geo- graphically and have never lived or been physically close to that team. In this sense, Brazil has shown itself to be an important market for the NBA, considering that at different times they have played off-season games in the country and have around 41 million fans ${ }^{7}$. This information raises a discussion about the motives that lead distant fans to connect with foreign teams, in this case, what makes Brazilian's consumers of the NBA.

Studies about the motives for sports consumption have been carried out for decades, highlighting the discussions started by Wann ${ }^{8}$, with the Sports Fan Motivation Scale, and the refinements presented by Trail and James ${ }^{9}$, with the Motivation Scale for Sport Consumption. From these conceptions, several motives are considered important for sports consumption, such as escape, drama and entertainment, aesthetics, social interaction, vicarious achievement, knowledge, physical attraction, and physical skills, among others ${ }^{9,10}$. In addition to identifying these dimensions, studies also point to the influence of different motives on fan consumption outcomes. Kim and Trail ${ }^{11}$, from the perspective of local fans, observed that attachment to the team motive was a dimension that influenced the presence of fans in the stadiums. In another important study carried out in Portugal, in the local basketball lea- 
gue, Biscaia, Correia, and Rosado ${ }^{12}$, based on the study by Won and Kitamura ${ }^{13}$, identified that motives such as family and vicarious achievement positively influenced satisfaction of the spectators at the games.

All organizations today must seek the loyalty of their consumers, as it means a strong commitment between fan and organization, which can mean a strong commitment to future consumption and referral to other people ${ }^{14}$. An important dimension to be analyzed about consumer loyalty in sport refers to their behavioral intentions, understood as the willingness to perform a certain behavior ${ }^{15}$, such as consuming products and services again, praising and recommending them. Understanding this dimension is important because a strong intention to perform a behavior increases the possibility of performing $\mathrm{it}^{16}$. In the case of distant fans, few investigations have identified the motives for the connection with sports teams and the influence on consumption and behavioral intentions. In an investigation carried out in China, $\mathrm{Pu}$ and James ${ }^{6}$ analyzed the motives for consuming the NBA and observed differences in the assessment of these dimensions and media consumption between different levels of connection with the teams through the Psychological Continuum Model ${ }^{17}$. However, further studies are needed to better identify the elements that can influence behavioral intentions.

Despite the existence of studies that consider the importance of understanding distant fans, few investigations have been carried out. This fact is aggravated when one observes the Brazilian reality and the lack of research that has analyzed the motives that lead Brazilians to stay connected and consume products and services from foreign teams. Information on this topic could provide clues for large sports companies, such as the NBA, to understand Brazilian consumers and perceive Brazil as an important market to invest in, as well as providing Brazilian companies with information to capture partnerships with sports organizations. Thus, the present investigation aimed to analyze, through games, the motives for the consumption of the NBA by Brazilian fans and the influence on the behavioral intentions of these fans.

\section{Methods}

The study has a quantitative approach, as the objective is an exploratory investigation and its design is considered a survey, widely used in research on Sport Management to allow researchers to collect desired information on a particular chosen sample ${ }^{18}$.

\section{Measures}

For data collection, a scale adapted from Biscaia, Correia, and Rosado ${ }^{12}$ and $\mathrm{Pu}$ and James ${ }^{6}$ was used, which analyzed the motives for the presence of basketball games in Portugal and the consumption of the NBA by distant fans, respectively. Although the study in Portugal did not consider distant fans, some motives presented were considered relevant to this investigation. The instrument was adapted by the authors to the Brazilian reality by changing words with the same meaning from Portuguese of Portugal to Portuguese of Brazil and by translating from English to Portuguese. The scale was made up of nine motives, three taken from the study by Biscaia, Correia and Rosado ${ }^{12}$, namely Family, Knowledge of the Game, and Drama, three from $\mathrm{Pu}$ and James ${ }^{6}$, namely Interest in Basketball, Acquisition of Knowledge, and Social Interaction. More three motives were similar in both studies, namely: Escape, Interest in Player, and Vicarious Achievement (To know the definition of each of these motives, see Table 1). In addition, the Behavioral Intentions dimension was included as a dependent variable, with three items, regarding the intentions to: "Watch more games", "Recommend other people to watch the team's games" and "Buy other products or services from the team." All dimensions of the instrument were measured by three items each and oper-

Table 1 - Definition of sport consumer motives in the study.

\begin{tabular}{|c|c|c|}
\hline Motives & Definition & Source \\
\hline Vicarious Achievement & It refers to a sense of accomplishment that is felt through the success of the sport team & Smith $^{10}$ \\
\hline Family & It refers to the sports opportunities to spend time together with the family in an organized and pleasurable way & Smith $^{10}$ \\
\hline $\begin{array}{l}\text { Knowledge of the } \\
\text { Game }\end{array}$ & $\begin{array}{l}\text { It refers to the knowledge that the consumer has about the sport, its tactical and technical aspects, and games } \\
\text { results }\end{array}$ & $\begin{array}{l}\text { Biscaia } \\
\text { et al. }{ }^{12}\end{array}$ \\
\hline Drama & $\begin{array}{l}\text { It refers to the theatrical experience that a fan can take part in through watching an engaging contest, enhancing } \\
\text { the sport's dramatic qualities }\end{array}$ & Smith $^{10}$ \\
\hline Escape & It refers to the environment provided by the sport as an escape from the ordinary routine of everyday life & Smith $^{10}$ \\
\hline Interest in Player & It refers to the interest in players with outstanding recognition & $\begin{array}{l}\text { Pu and } \\
\text { James }^{6}\end{array}$ \\
\hline Interest in Basketball & It refers to the interest in basketball as a whole & $\begin{array}{l}\text { Pu and } \\
\text { James }^{6}\end{array}$ \\
\hline $\begin{array}{l}\text { Acquisition of Knowl- } \\
\text { edge }\end{array}$ & It refers to the possibility of obtaining knowledge about the sport & $\begin{array}{l}\text { Pu and } \\
\text { James }^{6}\end{array}$ \\
\hline Social Interaction & It refers to the sports opportunities to spend time together with friends in an organized and pleasurable way & Smith $^{10}$ \\
\hline
\end{tabular}


ationalized by a 7-point Likert scale, where $1=$ Totally Disagree/Unlikely and $7=$ Totally Agree/Very Likely. At the end, sociodemographic questions about individuals and NBA consumption were included.

\section{Procedure}

The instrument was placed on the Google Forms online platform and disseminated through social media from January to March 2021, featuring a non-probabilistic convenience collection ${ }^{19}$. Before completing the items, all fans were informed about the research objectives through the Informed Consent Form, and when they agreed, they were redirected to fill out the questionnaire. This study is approved within a larger project, approved by an ethics committee of a Brazilian public university, with CAAE number 09700519.9.0000.5192 and protocol number 3.269.811.

Sample

Initially, the questionnaire was completed by 480 individuals. Two exclusion criteria were considered in the composition of the sample: 1) subjects under 18 years of age, and 2) individuals who do not support an NBA team. Thus, based on exclusion criterion 1), 112 responses were excluded, and on criterion 2), 25. In addition, the exploratory data analysis allowed the removal of seven observations that were considered more severe outliers. Finally, the sample was composed of 336 individuals, residing in Brazil, all over the age of 18 , who declared themselves to be fans of an NBA team and who had watched at least one NBA game in the period 2020/2021.

\section{Data analysis}

Data were analyzed using a two-step Structural Equation Modeling (SEM) ${ }^{20}$. In the first step, a Confirmatory Factor Analysis (CFA) was performed to analyze the proposed scale measurement model. Data normality was analyzed through skewness (between 3.0 and -3.0) and kurtosis (between 10.0 and -10.0) coefficients and the existence of outliers through the Mahalanobis distance $\left(\mathrm{D}^{2}\right)^{20}$. The reliability of the dimensions was assessed using Composite Reliability and considered acceptable for values $>0.70^{21}$, the factor validity was accepted when the value of the factorial loadings of the items were $>0.50^{22}$, the convergent validity was accepted for values of Average Variance Extracted (AVE) $>0.50$ and discriminant validity when the AVE of the factors was equal to or greater than the square of the correlation between these same factors ${ }^{21}$. In addition, the following indices were considered for the analysis of the model's fit: ratio of $\mathrm{X}^{2}$ by degrees of freedom $\left(\mathrm{X}^{2} / \mathrm{df}\right)$, Comparative Fit Index (CFI), Goodness of Fit Index (GFI), Root Mean Square Error of Approximation (RMSEA), and Tucker-Lewis Index (TLI).

In the second step, the structural model was analyzed to test the influence of motives on the individuals' beha- vioral intentions. Analyses were performed using AMOS 26.0 software and the established significance level was $\mathrm{p}<0.05$.

\section{Results}

Sociodemographic data referring to the sample are presented in Table 2, together with information on NBArelated consumption.

From the exploration of Table 2, it is possible to observe that, in general, the sample was composed of

Table 2 - Sociodemographic data and sample consumption information.

\begin{tabular}{|c|c|c|c|c|}
\hline & & M (SD) & $n$ (336) & $\%$ \\
\hline Age & & $\begin{array}{l}24.20 \\
(6.79)\end{array}$ & & \\
\hline \multirow[t]{2}{*}{ Sex } & Male & & 308 & 91.7 \\
\hline & Female & & 28 & 8.3 \\
\hline \multirow[t]{4}{*}{ Level of education } & Elementary school & & 3 & 0.9 \\
\hline & High school & & 154 & 45.8 \\
\hline & University education & & 144 & 42.9 \\
\hline & Postgraduate studies & & 35 & 10.4 \\
\hline \multirow{5}{*}{$\begin{array}{l}\text { Region of the country } \\
\text { where you live }\end{array}$} & North & & 10 & 3.0 \\
\hline & Northeast & & 148 & 44.0 \\
\hline & Midwest & & 14 & 4.2 \\
\hline & Southeast & & 123 & 36.6 \\
\hline & South & & 41 & 12.2 \\
\hline \multirow[t]{3}{*}{ Marital status } & Not married & & 281 & 83.6 \\
\hline & Married & & 52 & 15.5 \\
\hline & Divorced & & 3 & 0.9 \\
\hline \multirow[t]{4}{*}{ Professional situation } & Employee & & 138 & 41.1 \\
\hline & Unemployed & & 138 & 41.1 \\
\hline & Autonomous & & 58 & 17.3 \\
\hline & Retiree & & 2 & 0.6 \\
\hline \multirow{3}{*}{$\begin{array}{l}\text { Where do you watch } \\
\text { NBA games? }\end{array}$} & Internet & & 191 & 56.8 \\
\hline & Cable TV & & 134 & 39.9 \\
\hline & Open TV & & 11 & 3.3 \\
\hline \multirow{4}{*}{$\begin{array}{l}\text { How many NBA } \\
\text { games do you watch } \\
\text { a week? }\end{array}$} & 1 & & 22 & 6.5 \\
\hline & 2 & & 55 & 16.4 \\
\hline & 3 to 5 & & 180 & 53.6 \\
\hline & More than 5 & & 89 & 23.6 \\
\hline \multirow{2}{*}{$\begin{array}{l}\text { Do you buy licensed } \\
\text { NBA products? }\end{array}$} & No & & 195 & 58.0 \\
\hline & Yes & & 141 & 42.0 \\
\hline \multirow{5}{*}{$\begin{array}{l}\text { How many NBA } \\
\text { licensed products did } \\
\text { you buy in } 2020 ?\end{array}$} & 0 & & 169 & 50.3 \\
\hline & 1 & & 56 & 16.7 \\
\hline & 2 & & 39 & 11.6 \\
\hline & 3 to 5 & & 59 & 17.6 \\
\hline & More than 5 & & 13 & 3.9 \\
\hline
\end{tabular}

Note: $\mathrm{M}=$ Mean; $\mathrm{SD}=$ Standard deviation 
mostly men, young, single, and living in the Northeast region. Complementarily, the teams that fans indicated the most were the Los Angeles Lakers $(\mathrm{n}=72)$, Golden State Warriors $(\mathrm{n}=44)$, and Miami Heat $(\mathrm{n}=37)$. When asked about an NBA player, $316(94.0 \%)$ indicated they had a favorite player and the three most cited were LeBron James $(\mathrm{n}=104)$, Stephen Curry $(\mathrm{n}=50)$, and Kevin Durant $(\mathrm{n}=16)$.

In the first stage of data analysis, all items presented normal distribution based on skewness and kurtosis values. On the other hand, an item in the dimension Interest in Player had a factor loading below 0.50, and the AVE of the Drama dimension was below 0.50. The strategy used to maintain the two dimensions was the removal of the item with a low load in the first dimension and the removal of the item with the lowest factor loading in the Drama dimension. Although the use of at least three items is recommended for the operationalization of latent variables, different studies have already pointed out the possibility of using only one item per dimension ${ }^{23}$, also considering the need for sufficient information for the identification of the model ${ }^{22}$. Thus, a new CFA was performed, with the removal of the two items already mentioned, and good adjustment of the model was observed $\left[\chi^{2}(239)=463.39(\mathrm{p}<0.001), \chi^{2} / \mathrm{df}=1.93, \mathrm{GFI}=0.90\right.$, $\mathrm{TLI}=0.93$, CFI $=0.94$, RMSEA $=0.05(\mathrm{CI}=0.046-$ $0.060)$ ]. Through Table 3 , it is possible to verify the acceptable values for the factor loading of the items, the composite reliability, and the AVE of the factors. The mean of the dimensions was also analyzed. Table 4 shows the results of the analysis of discriminant validity, where all AVEs were above the square of the correlation of the analyzed dimensions. Although the reliability of the Drama dimension was below the cutoff point (0.70), the dimension was maintained by the authors, as the value was only marginally below.

After completing the first step of the analysis, the second step sought to analyze the proposed causal model. The CFA of the measurement model with the addition of the behavioral intentions dimension again showed a good fit of the model $\left[\chi^{2}(305)=642.17(\mathrm{p}<0.001)\right.$, $\chi^{2} / \mathrm{df}=2.10$, GFI $=0.88$, TLI $=0.92$, CFI $=0.93$, RMSEA $=0.05(\mathrm{CI}=0.050-0.062)]$. The added dimension presented normality of the data from the skewness and kurtosis values, as well as factor loadings $>0.50$ $(0.74 ; 0.71 ; 0.69)$ and AVE $(0.51)$. After confirming the qualities of the measurement model, the causal model was analyzed. The model presented a good fit to the data and the standardized estimates and significance of the trajectories are shown in Figure 1. The analysis indicated that the Vicarious Achievement and Social Interaction dimensions had a statistically significant influence on behavioral intentions. Furthermore, it is important to highlight that the proposed model was indicated as responsible for $63 \%$ $\left(\mathrm{R}^{2}=0.63\right)$ of the variability in behavioral intentions.

\section{Discussion}

This study aimed to analyze, through games, the motives for the consumption of the NBA by Brazilian fans and the influence on the behavioral intentions of these fans. The analysis of distant fans is an important theme to be developed, given the need for sports organizations to expand their market when thinking about the sport as a business. The results presented in this study could provide important information for making strategic decisions about actions that can be taken considering the motives for the consumption of the NBA in Brazil. Initially, the importance of validating a measurement instrument on the motives for consuming the NBA in the Brazilian reality is highlighted. In addition to the considerations of Trail and James $^{9}$ about the psychometric quality of the measure concerning previous studies, the present investigation presented reliability and validity values according to the literature, thus affirming the possibility of using the instrument in future investigations.

The analysis of means indicates that the drama $(\mathrm{M}=6.40 ; \mathrm{SD}=0.93)$ associated with NBA matches was the main motive for consumption. This finding is important because this motive was not analyzed by $\mathrm{Pu}$ and James $^{6}$, due to statistical problems in the dimension, and demonstrates the importance of this construct to distant fans as well. In a certain way, there is a consensus about the importance of drama to sport consumption from a local fan perspective. For instance, Biscaia, Correia, and Rosado $^{12}$ observed that drama was the motive with the highest mean to attend basketball games among men and women. In a comparison of three different college sports, James and Ross ${ }^{24}$ found that drama was one of the motives with the highest mean, behind entertainment and skill. Moreover, Kim, Magnusen, Kim, and Lee ${ }^{25}$ observed that drama is an important factor to the fan, which has a significant influence on the presence of fans at sporting events. For Smith ${ }^{10}$, drama and entertainment are important motives for sports consumption, because, in the act of watching a competition that allows for greater involvement, fans can feel they are participating in an almost theatrical experience.

Four other dimensions are also noteworthy when observing their averages. The motives acquisition of knowledge $(\mathrm{M}=6.33$; $\mathrm{SD}=0.89)$, interest in basketball $(\mathrm{M}=6.20 ; \mathrm{SD}=1.14)$, knowledge of the game $(\mathrm{M}=5.81$; $\mathrm{SD}=1.26)$, and vicarious achievement $(\mathrm{M}=5.80$; $\mathrm{SD}=1.28$ ), respectively, had the highest means after drama. Similarly, Pu and James ${ }^{6}$ found that acquisition of knowledge and interest in basketball was also dimensions with high means, showing their importance in considering these motives for the distant fans. Moreover, Funk, Mahony, and Ridinger ${ }^{26}$ highlighted the importance of the interest in sport, given that in their study about women's sport, a high level of spectator support was associated with 
Table 3 - Factor loadings, composite reliability, convergent validity, and dimension means.

\begin{tabular}{|c|c|c|c|c|}
\hline ITEMS & M (SD) & $\lambda$ & $\mathbf{C R}$ & AVE \\
\hline 1. Vicarious Achievement (VA) & $5.80(1.28)$ & & 0.84 & 0.63 \\
\hline I feel a personal sense of achievement when my NBA team wins. & & 0.78 & & \\
\hline I feel like I have won when my NBA team wins & & 0.76 & & \\
\hline I feel proud when my NBA team plays well & & 0.84 & & \\
\hline 2. Family (FAM) & $2.75(1.59)$ & & 0.88 & 0.71 \\
\hline Being with the family is the reason I enjoy watching NBA games & & 0.76 & & \\
\hline NBA games allow me to spend time with my family & & 0.95 & & \\
\hline Watching NBA games allows me to bond with my family & & 0.81 & & \\
\hline 3. Knowledge of the Game $(K G)$ & $5.81(1.26)$ & & 0.80 & 0.57 \\
\hline I regularly read my NBA team's results and statistics & & 0.76 & & \\
\hline I usually know the results of NBA teams & & 0.69 & & \\
\hline I regularly follow the NBA player stats & & 0.80 & & \\
\hline 4. Drama (DRA) & $6.40(0.93)$ & & 0.69 & 0.53 \\
\hline I like the game best when it is played to the end & & 0.74 & & \\
\hline I like to watch games where the outcome is uncertain & & 0.72 & & \\
\hline 5. Escape (ESC) & $5.08(1.59)$ & & 0.86 & 0.68 \\
\hline Watching NBA games allows me to escape from everyday reality & & 0.94 & & \\
\hline NBA games are an escape from my daily routine & & 0.78 & & \\
\hline I enjoy watching NBA games because I forget about my problems & & 0.74 & & \\
\hline 6. Interest in Player (IP) & $3.93(2.14)$ & & 0.86 & 0.76 \\
\hline I watch NBA games more because of certain players than the team & & 0.83 & & \\
\hline I am more a fan of individual players than I am of the team & & 0.91 & & \\
\hline 7. Interest in Basketball (IB) & $6.20(1.14)$ & & 0.86 & 0.68 \\
\hline First and foremost, I consider myself a fan of basketball & & 0.76 & & \\
\hline I love to follow the game of basketball & & 0.86 & & \\
\hline I am a huge fan of basketball in general & & 0.84 & & \\
\hline 8. Acquisition of Knowledge (AK) & $6.33(0.89)$ & & 0.77 & 0.54 \\
\hline I can increase my knowledge about basketball by watching NBA games & & 0.50 & & \\
\hline I can increase my understanding of the strategy by watching the game & & 0.83 & & \\
\hline I can learn about the technical aspects by watching NBA games & & 0.82 & & \\
\hline 9. Social Interaction (SI) & $4.25(1.52)$ & & 0.75 & 0.51 \\
\hline Watching NBA games gives me a chance to meet new people & & 0.59 & & \\
\hline Watching NBA games leads me to improve social relationships & & 0.83 & & \\
\hline Watching NBA games gives me the chance to spend time with my friends & & 0.70 & & \\
\hline
\end{tabular}

Note: $\mathrm{M}=$ Mean; $\mathrm{SD}=$ Standard deviation; $\lambda=$ Factor loading; $\mathrm{CR}=$ Composite reliability; AVE = Average Variance Extracted.

Table 4 - Discriminant validity between motives for NBA consumption.

\begin{tabular}{ccccccccccc}
\hline & & VA & FAM & KG & DRA & ESC & IP & IB & AK & SI \\
& AVE & 0.63 & 0.71 & 0.57 & 0.53 & 0.68 & 0.76 & 0.68 & 0.54 \\
VA & 0.63 & 1 & & & & & & & \\
FAM & 0.71 & 0.04 & 1 & & & & & & \\
KG & 0.57 & 0.27 & 0.03 & 1 & & & & & \\
DRA & 0.53 & 0.00 & 0.03 & 0.06 & 1 & & & & \\
ESC & 0.68 & 0.26 & 0.04 & 0.21 & 0.03 & 1 & & & \\
IP & 0.76 & 0.04 & 0.00 & 0.00 & 0.04 & 0.01 & 1 & & \\
IB & 0.68 & 0.31 & 0.06 & 0.34 & 0.06 & 0.24 & 0.00 & & 1 \\
AK & 0.54 & 0.19 & 0.03 & 0.16 & 0.06 & 0.11 & 0.00 & 0.17 & \\
SI & 0.51 & 0.10 & 0.37 & 0.04 & 0.03 & 0.21 & 0.00 & 0.14 & 0.06 \\
\hline
\end{tabular}

Note: AVE = Average Variance Extracted; VA = Vicarious Achievement; FAM = Family; KG = Knowledge of the Game; DRA = Drama; ESC = Escape; I

$=$ Interest in Player; $\mathrm{IB}=$ Interest in Basketball; $\mathrm{AK}=$ Acquisition of Knowledge; SI = Social Interaction. 


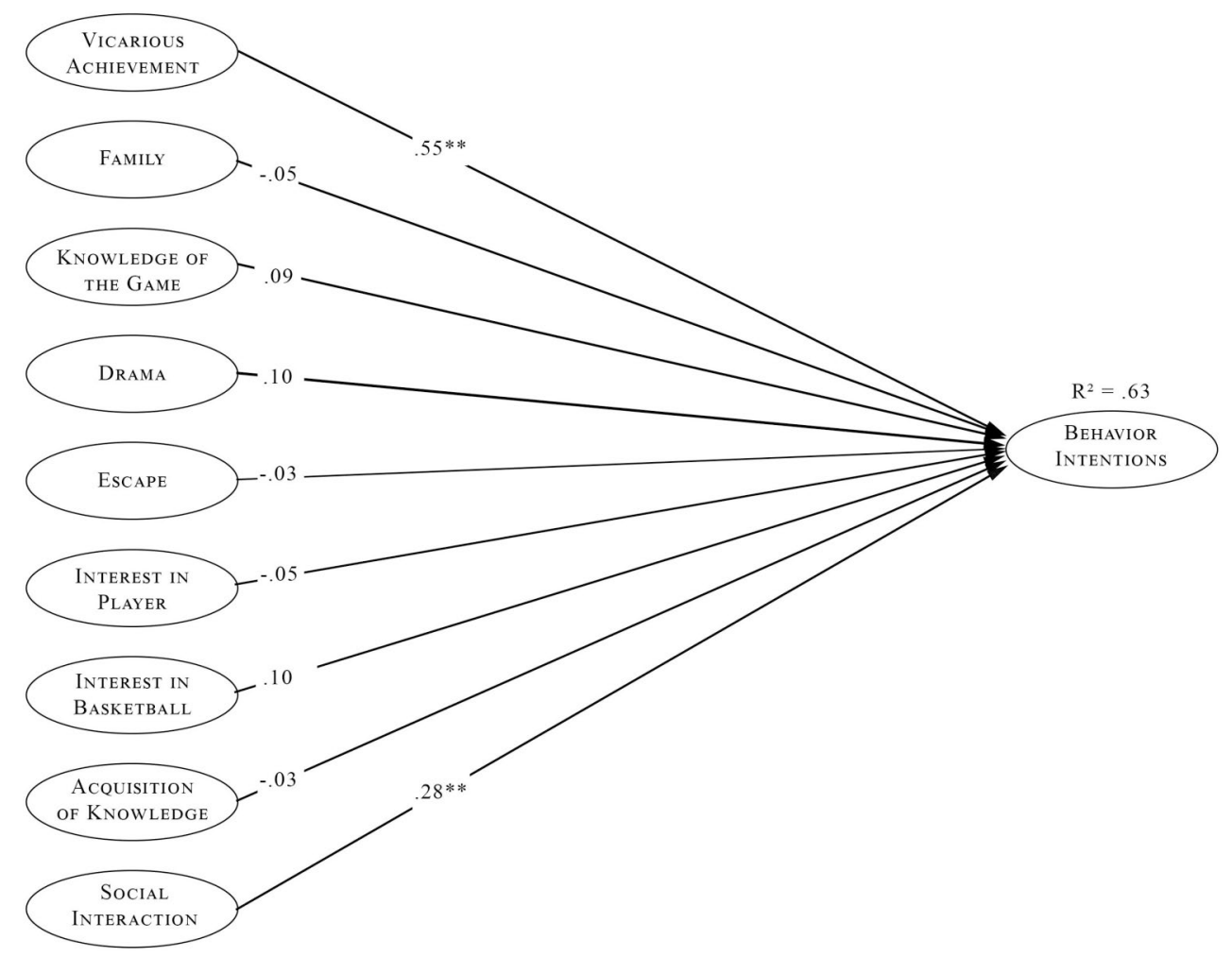

Figure 1 - Proposed causal model for the analysis of motives for consuming the NBA on behavioral intentions. Note: ** $=\mathrm{p}<0.01$.

a strong interest in soccer. Knowledge associated with sports consumption seems to be an important motive as well, considering that people support their NBA team to obtain knowledge related to the game and because of their pre-existing knowledge. Also, Biscaia, Correia, and Rosado $^{12}$ identified that knowledge of the game is an important motive in basketball consumption. In their research, men values knowledge of technical-tactical aspects and game statistics more than women. Finally, the vicarious achievement is one of the most motives pointed in the literature when we talk about fan behavior ${ }^{27}$. This is important because, even though they don't have the faceto-face experience of a game, distant fans also have a sense of personal achievement when the team succeeds. Regarding the lowest mean, family $(\mathrm{M}=2.75 ; \mathrm{SD}=1.59)$ seems does not to be an important reason to consume NBA games. Actually, Trail, Fink, and Anderson ${ }^{28}$ have already identified a family with a low path coefficient loaded in a second-order latent variable motive, which may indicate that spending time with family members is not necessarily a motive ${ }^{29}$.

In general, these motives are presented as important indicators of strategies that can be used in the promotion of sports teams. Even though it was not the objective of this investigation, the information reported here can help marketing strategies of the teams participating in the basketball league in Brazil (Novo Basquete Brasil - NBB), considering the importance of attracting more and more public to the games ${ }^{30}$. The fact that the NBB stimulates the interest of the Brazilian and international market, including in partnerships with the $\mathrm{NBA}^{31}$, demonstrates that the teams of NBB can consider the motives discussed here to increase the consumption of their games also for fans outside Brazil ${ }^{32}$.

Regarding the analysis of the causal model, the results of the present investigation showed that both vicarious achievement $(\beta=0.55 ; \mathrm{p}<0.01)$ and social interaction $(\beta=0.28 ; \mathrm{p}<0.01)$ are motives that positively influenced the fans' behavioral intentions. The importance of vicarious achievement in predicting fan behavior related to attendance at sports events is widely investigated ${ }^{33-}$ ${ }^{36}$. Through the theory of social identity, the vicarious achievement is understood as the desire on the part of someone to preserve a positive self-concept through the success achieved by an object ${ }^{37}$. It is known that individuals feel that they can share in the success of someone or an organization when they feel connected to them ${ }^{38}$. In the case of distant fans, the results indicate that this feeling of accomplishment owing to the sports team they support influences their behavioral intentions. In the study by $\mathrm{Pu}$ and James ${ }^{6}$, it was possible to observe that the mean for this dimension was higher for individuals with a high level of loyalty when compared to lower levels. All these elements underscore the importance of marketing campaigns to value the team's victories through social media, for instance, so that distant fans maintain this feeling of 
accomplishment, thus increasing the possibility of consumption. The vicarious achievement was also an important motive in the study of Biscaia, Correia, and Rosado ${ }^{12}$. In Portugal, this motive had a positive relationship with the satisfaction of local fans $(\beta=0.174 ; p<0.01)$.

In the case of social interaction, this motive is widely used in the literature on motives for sports consumption ${ }^{9,39,40}$. Trail and $\mathrm{Kim}^{41}$ also noted that internal motivators, including social interactions, were positively related to intentions to attend women's college basketball games in the United States of America. For the case of distant fans, the significant influence of this dimension is noteworthy because it emphasizes that, even though they are not able to follow the NBA games in the arenas, the possibility of interacting and meeting new people can influence the recommendation and consumption of the competition. This result may be related to the importance of using social networks as a form of social interaction or even with the possibility of bringing friends and family together during games. In a study on the motives of NBA fans concerning interaction on Facebook, Stavros, Meng, Westberg, and Farrelly ${ }^{42}$ observed that one of the four dimensions that emerged from the study was camaraderie. This dimension reflects a desire, on the part of fans, to identify and interact within the online community. Although the study mentioned above does not refer to interaction during games, this information highlights the use of social networks as an opportunity to be in contact with other fans.

\section{Conclusions}

Globalization, together with the development of the internet, has potentialized the capacity of sports organizations to expand their operations to markets that were previously extremely difficult or even unthinkable to reach in the way they do today. In a scenario where some of these organizations are considered global brands and thus true enterprises, establishing a fan base across geographic boundaries has become a necessity. In the case of the NBA, which can be considered the most important basketball league in the world, understanding the motives that make fans geographically far away from this competition continue to consume products and services related to it is fundamental. In the Brazilian market, motives such as the acquisition of knowledge, drama, interest in basketball, and knowledge of the game were highly valued by Brazilian fans who consume the NBA. Furthermore, the sense of accomplishment fans feels when their NBA team wins and the social interaction offered by the games in the competition, however distant, are important factors that influence behavioral intentions related to the American League. These results serve as information for the development of marketing strategies for teams that want to expand their activities in the Brazilian market and try to develop their brand with fans in Brazil.

As in any investigation, some limitations were observed in this study. First, because the sample was composed in a non-probabilistic way for convenience, the number of responses obtained, and the characteristics of the participants do not allow us to generalize the data throughout Brazil. Another limitation to be considered is the lack of analysis of the level of identification of fans with the teams they support. Future studies should collect this information so that they can, through a moderation analysis, for example, analyze the extent to which different levels of identification with the team can influence the relationship between motives and behavioral intentions. The third limitation refers to the lack of information gathered about the fans' past experiences with the teams they support or even with the NBA in any way. Consumers who have already watched an NBA game in the arena or had face-to-face experience with the team or league may rate the selected motives differently to those who have not had any face-to-face experience. Therefore, future studies should consider this information for the analysis of distant fans. Another study opportunity refers to the analysis of other sports leagues, in other modalities, in order to compare whether there are differences in the motives for consumption of distant fans when comparing different sports.

\section{References}

1. Bodet G, Séguin B. Team sports brand management. In: Managing sports teams - Economics, strategy and practice. Cham: Springer; 2021.

2. Deloitte. Deloitte Football Money League 20202020. Available from: https://www2.deloitte.com/uk/en/pages/ sports-business-group/articles/deloitte-football-money-lea gue.html\#.

3. Badenhausen K, Ozanian M. NBA team values 2021: Knicks keep top spot at \$5 Billion, while Warriors seize No. 2 from Lakers Forbes 2021 Available from: https://www.for bes.com/sites/kurtbadenhausen/2021/02/10/nba-teamvalues-2021-knicks-keep-top-spot-at-5-billion-warriorsbump-lakers-for-second-place/?sh=48b28254645b.

4. Chanavat N, Bodet G. Internationalisation and sport branding strategy: a French perception of the Big Four brands. Qual Mark Res. 2009;12(4):460-81.

5. Kerr AK, Gladden JM. Extending the understanding of professional team brand equity to the global marketplace. Int $\mathrm{J}$ Sport Manag Mark. 2008;3(1/2):58-77.

6. $\mathrm{Pu} \mathrm{H}$, James J. The distant fan segment: exploring motives and psychological connection of International National Basketball Association fans. Int J Sports Mark Spons. 2017;18 (4):418-38.

7. Serrano L. Brasil tem 41 milhões de fãs da NBA, diz pesquisa CNN Brasil2021. Available from: https://www.cnnbra sil.com.br/esporte/2020/09/29/brasil-tem-41-milhoes-defas-da-nba-diz-pesquisa. 
8. Wann DL. Preliminary validation of the sport fan motivation scale. J Sport Soc Issues. 1995;19(4):377-96.

9. Trail G, James J. The motivation scale for sport consumption: Assessment of the scale's psychometric properties. J Sport Behav. 2001;24(1):108-27.

10. Smith ACT. Introduction to sport marketing. Oxford: Butterworth-Heinemann; 2008.

11. Kim YK, Trail G. Constraints and motivators: a new model to explain sport consumer behavior. J Sport Manag. 2010;24 (2):190-210.

12. Biscaia R, Correia A, Rosado A. Determinantes da satisfação dos espectadores de basquetebol. Rev Port Ciênc Desporto. 2011;11(1):59-74.

13. Won J-u, Kitamura K. Comparative analysis of sport consumer motivations between South Korea and Japan. Sport Mark Q. 2007;16(2):93-105.

14. Dwyer B. Divided loyalty? An analysis of fantasy football involvement and fan loyalty to individual National Football League (NFL) teams. J Sport Manag. 2011;25(5):445-57.

15. Ajzen I. The theory of planned behavior. Organ Behav Hum Decis Process. 1991;50(2):179-211.

16. Park J-A, Sung J-M, Son J-M, Na K, Kim S-K. Athletes' brand equity, spectator satisfaction, and behavioral intentions. Asia Pacific J. Mark. Logist. 2019;31(2):541-58.

17. Funk D, James J. The psychological continuum model: a conceptual framework for understanding an individual's psychological connection to sport. Sport Manage Rev. 2001;4(2):119-50.

18. Andrew DPS, Pederson PM, McEvoy CD. Research methods and design in sport management. $1^{a}$ ed. Champaign: Human Kinects, Inc; 2011.

19. Skinner J, Edwards A, Corbett B. Research methods for sport management. $1^{\mathrm{a}}$ ed. New York: Routledge; 2014.

20. Marôco J. Análise de equações estruturais: fundamentos teóricos, softwares \& aplicações. $2^{\mathrm{a}}$ ed. Pêro Pinheiro: ReportNumber; 2014.

21. Fornell C, Larcker DF. Evaluating structural equation models with unobservable variables and measurement error. J Mark Res. 1981;18(1):39-50.

22. Hair JF, Black WC, Babin BJ, Anderson RE. Multivariate data analysis. $7^{\mathrm{a}}$ ed. Harlow: Pearson; 2009.

23. Rossiter JR. The C-OAR-SE procedure for scale development in marketing. Int J Res Mark. 2002;19:305-35.

24. James J, Ross S. Comparing sport consumer motivations across multiple sports. Sport Mark Q. 2004;13(1):17-25.

25. Kim Y, Magnusen M, Kim M, Lee H-W. Meta-analytic review of sport consumption: factors affecting attendance to sporting events. Sport Mark Q. 2019;28(3):117-34.

26. Funk D, Mahony D, Ridinger L. Characterizing consumer motivation as individual difference factors: augmenting the Sport Interest Inventory (SII) to explain the level of spectator support. Sport Mark Q. 2002;11(1):33-43.

27. Fazal-E-Hasan SM, Neale L, Sekhon H, Mortimer G, Brittain I, Sekhon J. The path to game-day attendance runs through sports fan rituals. J Bus Res. 2021;137:308-18.

28. Trail GT, Fink JS, Anderson DF. Sport spectator consumption behavior. Sport Mark Q. 2003;12(1):8-17.

29. Trail GT, Robinson MJ, Dick RJ, Gillentine AJ. Motives and points of attachment: fans versus spectators in intercollegiate athletics. Sport Mark Q. 2003;12(4):217-27.
30. Capinussú JM, Lima WA. O retorno dos patrocinadores do Novo Basquete Brasil. Rev Intercont Gest Desport. 2011;1 (2):122-31

31. Globo Esporte. NBA cresce $50 \%$ em dois anos no Brasil, que não pode receber jogos: "não possui arena em condições", 2021 Available from: https:/ge.globo.com/nego cios-do-esporte/noticia/nba-cresce-50percent-em-dois-anosno-brasil-que-nao-pode-receber-jogos-nao-possui-arenaem-condicoes.ghtml.

32. Hirata E, Canan F, Melleiro JPM, Starepravo FA. Análise do potencial mercantil do Novo Basquete Brasil (2008-2018). EBM-J Sport Sci. 2019;15(2):151-8.

33. Gencer RT, Kiremitci O, Boyacioglu H. Spectator motives and points of attachment: an investigation on professional basketball. J Hum Kinet. 2011;30:189-96.

34. Kim S, Morgan A, Assaker G. Examining the relationship between sport spectator motivation, involvement, and loyalty: A structural model in the context of Australian Rules football. Sport Soc. 2021;24(6):1006-32.

35. Pizzo AD, Baker B, Na S, Lee MA, Kim D, Funk D. eSport vs. Sport: a comparison of spectator motives. Sport Mark Q. 2018;27(2):108-23.

36. Yenilmez MI, Ersöz G, Çinarli S, Sari İ. Examination of the psychometric properties of the sport interest inventory in a sample of Turkish football spectators. Manag Sport Leis. 2020;25(4):246-58.

37. Wu S-H, Tsai C-YD, Hung C-C. Toward team or player? How trust, vicarious achievement motive, and identification affect fan loyalty. J Sport Manag. 2012;26(22):177-91.

38. Cialdini RB, Borden RJ, Thorne A, Walker MR, Freeman S, Sloan LR. Basking in reflected glory: three (football) field studies. J Pers Soc Psychol. 1976;34(3):366-75.

39. Silveira MP, Cardoso MV, Quevedo-Silva F. Factors influencing attendance at stadiums and arenas. Mark Intell Plan. 2019;37(1):50-65.

40. Mayer KC, Hungenberg E. Sport attendance behavior spectrum: motivators, constraints and context. Int J Sports Mark Spons. 2020;22(3):566-87.

41. Trail G, Kim YK. Factors influencing spectator sports consumption: NCAA women's college basketball. Int J Sports Mark Spons. 2011;13(1):55-77.

42. Stavros C, Meng MD, Westberg K, Farrelly F. Understanding fan motivation for interacting on social media. Sport Manage Rev. 2014;17(4):455-69.

\section{Corresponding author}

Yves Miranda, Universidade de Pernambuco, Grupo de Pesquisa em Esporte e Gestão, Recife, PE, Brazil.

E-mail: miranda95y@gmail.com.

Manuscript received on July 3, 2021

Manuscript accepted on October 27, 2021

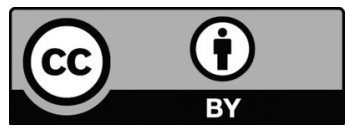

Motriz. The Journal of Physical Education. UNESP. Rio Claro, SP, Brazil - eISSN: 1980-6574 - under a license Creative Commons - Version 4.0 